\title{
Effect of pretreatment clinical factors on overall survival in glioblastoma multiforme: a Surveillance Epidemiology and End Results (SEER) population analysis
}

Sudheer R Thumma ${ }^{1,2}$, Robert K Fairbanks ${ }^{1,2}$, Wayne T Lamoreaux ${ }^{1,2}$, Alexander R Mackay ${ }^{1,3}$, John J Demakas ${ }^{1,4}$, Barton S Cooke ${ }^{1}$, Ameer L Elaimy ${ }^{1,2}$, Peter W Hanson ${ }^{1,2}$ and Christopher M Lee ${ }^{1,2,5^{*}}$

\begin{abstract}
Background: Glioblastoma Multiforme (GBM) is one of the most aggressive primary brain tumors and is associated with a dismal prognosis. The median survival after the primary diagnosis remains poor, even after multimodal treatment approaches. However, a few patients have been reported to have long term survival greater than three years. A number of studies have attempted to define factors capable of predicting long term outcomes in specific patient groups. This article reports the outcomes of a very large group of patients diagnosed with GBM, and analyzes specific prognostic factors known to influence survival in these patients.

Methods: We used the Surveillance, Epidemiology, and End Results (SEER) database of the US National Cancer Institute $(\mathrm{NCl})$ to investigate various patient-related and treatment- related factors that could influence the long term survival in patients diagnosed with glioblastoma. A total of 34,664 patients aged 20 years or older with a diagnosis of GBM during the years 1973 to 2008 were studied. Overall survival outcomes were examined with Kaplan-Meier survival analysis and Cox hazard models.

Results: Asian/Pacific Islanders had a better survival compared to the white population $(P=<0.001)$. Patients diagnosed with GBM during the years 2000 to 2008 had a superior survival rate when compared with earlier decades $(P=<0.001)$. Statistically significant improvements in overall survival were also found for patients who received surgical resections, and adjuvant radiation treatment versus no radiation ( $P$-values $<0.001$ ). Young age was also found to be highly predictive of improved overall survival rates when separated into age groups as well as when studied as a continuous variable.
\end{abstract}

Conclusions: Clinical pretreatment and treatment factors, including young age at diagnosis, Asian/Pacific Islander ethnicity, recent year of diagnosis, surgical resection and the use of adjuvant radiation therapy favorably influence survival in patients diagnosed with glioblastoma.

Trial Registration: All data were obtained from the United States Surveillance Epidemiology and End Results (SEER) database.

Keywords: Glioblastoma, Asian ethnicity, Radiation, Age, Surgery, Radiation, Survival

\footnotetext{
*Correspondence: lee@ccnw.net

${ }^{1}$ The Gamma Knife of Spokane, Spokane, WA, USA

${ }^{2}$ Cancer Care Northwest, Spokane, WA, USA

Full list of author information is available at the end of the article
} 


\section{Background}

Glioblastoma remains one of the most aggressive and lethal forms of primary malignancy of the brain. However, recent advances in the diagnostics and treatments of glioblastoma have offered new hope for patients and clinicians. Despite these advances in therapy, the management of glioblastoma remains a challenge. Tumor factors such as deep infiltration of cancer cells with microscopic extensions into surrounding normal brain tissue, geographic location within the brain and a particular tumor's accessibility to surgical resection may present barriers to adequate surgical treatment. The blood-brain barrier's natural protection by filtration of large chemicals also limits the penetration of chemotherapeutic agents. Upon initial diagnosis, the standard treatment consists of surgery with maximal feasible resection, post-operative fractionated external beam radiation (standard dose ranges between 5,940 to 6,000 cGy in 180 to 200 cGy per fraction) with concomitant and adjuvant chemotherapy with temozolamide. The addition of temozolamide has been shown to improve overall survival. Despite this advance, the vast majority of patients still experience disease progression within a year [1].

Currently, there is not a single standard treatment for the recurrence of this tumor, although additional surgery, chemotherapy and radiotherapy are used in specific clinical circumstances. The types of salvage therapy are tailored to each patient's clinical situation. For example, stereotactic radiosurgery (SRS) and novel chemotherapy agents are increasingly used to treat the recurrent tumors. Because of these treatment advances, outcomes have changed dramatically for appropriately selected patients. Previous studies have revealed that pretreatment prognostic factors play a role in clinical outcomes $[2,3]$. Several small studies have identified clinical, tumor and treatment related prognostic factors that influence outcomes [4,5]. The clinical factors of age, Karnofsky performance status (KPS), extent of surgical resection, post-operative radiation treatment, degree of necrosis within the resection pathology, and the degree of enhancement on preoperative and postoperative MR imaging studies have been shown to influence survival $[6,7]$. Identifying different prognostic subgroups of patients may help tailor specific treatment regimens to improve outcomes. The purpose of this study is to better analyze important pretreatment and treatment factors in the United States population associated with improvements in overall survival for patients with glioblastoma.

\section{Methods}

All data were acquired from the 1997 to 2008 limited use databases of the Surveillance, Epidemiology, and End Results (SEER) Program of the US National Cancer Institute $(\mathrm{NCI})$, which contains data from geographically specified United States locations that span a population of approximately 30 million people. Registry data are submitted without personal identifiers; therefore, patient informed consent and ethics committee approval were not required to perform this analysis.

We examined 34,664 patients aged 20 years or older with a diagnosis of glioblastoma multiforme (GBM) between 1973 and 2008. The patients were grouped by race (White, Black, Asian/Pacific Islander, American Indian/ Alaska Native, Other, Unknown), diagnosis year (1973 to 1979, 1980 to 1989,1990 to 1999,2000 to 2008), radiation treatment (Yes, No, Unknown), extent of surgery (Surgical Resection, No Cancer Directed Resection, Unknown) and age at diagnosis $(<50,>/=50)$. Patients younger than 50 years were further sub-grouped into 10year age-bands. Chemotherapy as a prognostic variable was not included since details regarding this were not available in the SEER database. Numbers of patients in the racial groups, diagnosis year groups and age groups are shown in Table 1 and numbers of patients in the radiation treatment groups and extent of surgery groups are shown in Table 2. Similarly, the distributions of patients younger than 50 years into 10-year age-bands for these same groupings are shown in Tables 3 and 4 .

Survival curves were estimated using the Kaplan-Meier method and used to compare racial groups, diagnosis year groups, radiation treatment groups, extent of surgery groups and age groups. Andersen $95 \%$ confidence intervals for the median survival time of the groups were constructed. Peto's log-rank tests were employed to determine if there is statistical evidence of differences between the survival curves of the groups. Exact conditional maximum likelihood estimates were used to calculate the groups' hazard ratios and Fisher 95\% confidence intervals were constructed for significance testing between the groups' hazard ratios. To look at group differences between survival rates specifically at one-year, two-years, and five-years, absolute survival rates were calculated with $95 \%$ confidence intervals using a maximum likelihood solution from an asymptotic distribution by the transformation of survivorship $\left(\mathrm{l}_{\mathrm{x}}\right)$. Finally, the Cox proportional hazard model was used in a multivariate analysis of the racial, diagnosis year, radiation treatment, and extent of surgery categorical variables as well age as a continuous variable. Statistical significance was set at a $\mathrm{p}$ value $<0.05$. All statistical analyses utilized Stats Direct Version 2.5.7 (Stats Direct Ltd., Altrincham, UK) and Sigma Plot Version 11.0 (SYSTAT Software, Inc., San Jose, CA, USA).

\section{Results}

Kaplan-Meier survival curves for racial groups are depicted in Figure 1. There was a significant difference in survival of the Asian/Pacific Islander group as 
Table 1 Numbers of patients with GBM by racial groups, diagnosis year groups, and age groups

\begin{tabular}{|c|c|c|c|c|}
\hline & & \multicolumn{2}{|c|}{ Age Groups } & \multirow[b]{2}{*}{ Total } \\
\hline & & $<50$ & $>/=50$ & \\
\hline Racial Groups & $\begin{array}{l}\text { Diagnosis } \\
\text { Year Groups }\end{array}$ & & & \\
\hline \multirow[t]{4}{*}{ White } & 1973 to 1979 & 542 & 2,149 & 2,691 \\
\hline & 1980 to 1989 & 677 & 3,587 & 4,264 \\
\hline & 1990 to 1999 & 1,226 & 6,307 & 7,533 \\
\hline & 2000 to 2008 & 2,634 & 14,698 & 17,332 \\
\hline White Total & & 5,079 & 26,741 & 31,820 \\
\hline \multirow[t]{4}{*}{ Black } & 1973 to 1979 & 26 & 79 & 105 \\
\hline & 1980 to 1989 & 59 & 112 & 171 \\
\hline & 1990 to 1999 & 83 & 287 & 370 \\
\hline & 2000 to 2008 & 179 & 701 & 880 \\
\hline Black Total & & 347 & 1,179 & 1,526 \\
\hline \multirow{4}{*}{$\begin{array}{l}\text { Asian/ } \\
\text { Pacific Islander }\end{array}$} & 1973 to 1979 & 14 & 24 & 38 \\
\hline & 1980 to 1989 & 23 & 64 & 87 \\
\hline & 1990 to 1999 & 80 & 248 & 328 \\
\hline & 2000 to 2008 & 154 & 570 & 724 \\
\hline $\begin{array}{l}\text { Asian/Pacific } \\
\text { Islander Total }\end{array}$ & & 271 & 906 & 1,117 \\
\hline \multirow{4}{*}{$\begin{array}{l}\text { American Indian/ } \\
\text { Alaska Native }\end{array}$} & 1973 to 1979 & - & - & - \\
\hline & 1980 to 1989 & - & 2 & 2 \\
\hline & 1990 to 1999 & 6 & 18 & 24 \\
\hline & 2000 to 2008 & 17 & 44 & 61 \\
\hline $\begin{array}{l}\text { American Indian/ } \\
\text { Alaska Native Total }\end{array}$ & & 23 & 64 & 87 \\
\hline \multirow[t]{4}{*}{ Unknown } & 1973 to 1979 & - & 2 & 2 \\
\hline & 1980 to 1989 & 2 & 2 & 4 \\
\hline & 1990 to 1999 & 3 & 6 & 9 \\
\hline & 2000 to 2008 & 5 & 19 & 24 \\
\hline Unknown Total & & 10 & 29 & 39 \\
\hline \multirow[t]{4}{*}{ Other } & 1973 to 1979 & - & - & - \\
\hline & 1980 to 1989 & - & - & - \\
\hline & 1990 to 1999 & - & 1 & 1 \\
\hline & 2000 to 2008 & 2 & 12 & 14 \\
\hline Other Total & & 2 & 13 & 15 \\
\hline \multirow[t]{4}{*}{ All Races } & 1973 to 1979 & 582 & 2,254 & 2,836 \\
\hline & 1980 to 1989 & 761 & 3,767 & 4,528 \\
\hline & 1990 to 1999 & 1,398 & 6,867 & 8,265 \\
\hline & 2000 to 2008 & 2,991 & 16,044 & 19,035 \\
\hline All Races Total & & 5,732 & 28,932 & 34,664 \\
\hline
\end{tabular}

compared to the White group of patients. There was also evidence of significantly improved survival for patients diagnosed in 2000 to 2008 as compared to earlier years as depicted in Figure 2. Surgical resection and the use of adjuvant radiation treatment were associated with significantly improved survival outcomes as shown in Figures 3 and 4. Likewise, Figure 4 depicts improved survival for patients undergoing surgical resection. Figures 5 and 6 show significantly improved survival for patients diagnosed at younger ages.

Univariate median survival confidence interval and hazard ratio confidence intervals are included in Table 5. For each category, a reference group was selected (Race $=$ White, Diagnosis year $=1973$ to 1979, Radiation treatment $=$ Yes, Extent of Surgery $=$ surgical resection, Age $=/<50$ years, Ten-year age-band $=20$ to 29 years) against which the other group's hazard ratios were tested. The hazard ratios of the Asian/Pacific Islander and Other racial groups were found to be statistically superior to the White group $(P<0.001$ and $P=0.009$ respectively). All three of the later diagnosis year groups' hazard ratios were found to be improved as compared to the reference group of 1973 to $1979(P=0.005$ for both the 1980 to 1989 and 1990 to 1999 groups, $P<0.001$ for the 2000 to 2008 group). Both the "No radiation" and "Unknown radiation" hazard ratios were determined to be inferior as compared to the "Yes radiation" reference group $(P<0.001$ in both cases). The patients in the "No Cancer Directed Resection" group were found to have less favorable outcomes as compared to the Surgical Resection reference group $(P<0.001)$. Finally, all three variations of reviewing the impact of age indicated that patients diagnosed at older ages had less favorable hazard experiences $(P<0.001)$. Univariate $1-, 2$-, and 5 -year absolute survival rates for groups were also examined and are shown in Table 6. Significance was declared for a value $<0.025$. Survival rate comparisons yielded broadly similar results as the univariate hazard ratio tests.

The multivariate analysis hazard ratio estimates and confidence intervals are included in Table 7. The multivariate analysis utilized the same reference groups as the univariate analyses against which the other group's hazard ratios were tested. Similar to the univariate analysis, the Asian/Pacific Islander and Other racial group's hazard ratios were significantly better than the reference group of White patients $(P<0.001$ and $P=0.002$, respectively). Likewise, we found similar results regarding the diagnosis year groups in that, all three later diagnosis groupings (1980 to 1989, 1990 to 1999,2000 to 2008) had significantly superior survival as compared to the reference 1973 to 1979 group $(P<0.001$ in all three cases). In both the radiation and extent of surgery categorical variables, the multivariate analysis found significantly better outcomes for the reference group compared to others $(P<0.001$ in all cases). In the multivariate analysis age was also examined as a continuous variable and was found to significantly impact overall survival $(P<0.001)$ 
Table 2 Numbers of patients with GBM by radiation treatment groups, extent of surgery groups, and age groups

\begin{tabular}{|c|c|c|c|c|}
\hline & & & & \\
\hline & & $<50$ & $>=50$ & Total \\
\hline Radiation Groups & Extent of Surgery Groups & & & \\
\hline Yes & Surgical Resection & 3,838 & 14,216 & 18,054 \\
\hline & No Cancer Directed Resection & 548 & 3,764 & 4,312 \\
\hline & Unknown & 159 & 861 & 1,020 \\
\hline Yes Total & & 4,545 & 18,841 & 23,386 \\
\hline No & Surgical Resection & 654 & 4,498 & 5,152 \\
\hline & No Cancer Directed Resection & 297 & 3,788 & 4,085 \\
\hline & Unknown & 92 & 845 & 937 \\
\hline No Total & & 1,043 & 9,131 & 10,174 \\
\hline Unknown & Surgical Resection & 91 & 505 & 596 \\
\hline & No Cancer Directed Resection & 19 & 195 & 214 \\
\hline & Unknown & 34 & 260 & 294 \\
\hline Unknown Total & & 144 & 960 & 1,104 \\
\hline All Radiation Groups & Surgical Resection & 4,583 & 19,219 & 23,802 \\
\hline & No Cancer Directed Resection & 864 & 7,747 & 8,611 \\
\hline & Unknown & 285 & 1,966 & 2,251 \\
\hline All Radiation Groups & & 5,732 & 28,932 & 34,664 \\
\hline
\end{tabular}

with an estimated hazard ratio of 1.037 (95\% CI 1.036 to 1.038). Thus, younger age was associated with an improved survival rate.

\section{Discussion}

The median survival after the primary diagnosis in patients with GBM is 12 to 16 months [8]. The patients who survive more than three years after the diagnosis are described as long term survivors [9]. It is not clear as to why a small subgroup of patients have significantly better outcomes and this could be related to clinical-, tumor- or treatment-related factors or other unknown variables. We found that the clinical factors of age less than 50 years, Asian race, surgical resection of the tumor, adjuvant radiation treatment and recent diagnosis year from 2000 to 2008 correlated with improved survival.

Most authors agree that young age at presentation is a predictor of long term survival in patients with glioblastoma $[3,10]$. In our study, when compared to the " $<50$ years" group, the " $>50$ years" group showed a significant decrease in survival (hazard ratio 2.22; 95\% CI, 2.17 to 2.33 ; $P=<0.001)$. When compared to "20 to 29 " group, the "30 to 39 year" group (hazard ratio 1.23; $95 \%$ CI, 1.10 to $1.39 ; P=<0.001)$ and "40 to 49 year" group (hazard ratio $1.85 ; 95 \% \mathrm{CI}, 1.67$ to $2.04 ; P=<0.001$ ) showed statistically significant decreased survival. Also, for every year increase in patient age, there was a significant decrease in survival (hazard ratio 1.037; 95\% CI, 1.036 to $1.038 ; P=<0.001$ ), which is a unique finding in our study. Our study results are consistent with several studies done in the past. In 1993, Chandler et al. estimated a mean age of 39.2 years in a group of 22 long term survivors with a median duration of survival of 9.4 years [11]. Scott et al. reported that $2.2 \%(n=15)$ of a series of 689 glioblastoma patients survived more than three years, and had a mean age of $43.5+/-3.3$ years [12]. Sneed et al. conducted a retrospective review to study the influence of age on the survival of patients with glioblastoma treated with radiotherapy and a brachytherapy boost. The univariate and multivariate analyses showed age as the most significant factor influencing survival $(P=<.0005)$ and patients younger than 29.9 years had the highest probability of long term survival [13]. Studies by Ohgaki et al. reported that patients diagnosed with secondary GBM (GBMs arising from lower grade CNS tumors) survived significantly longer than those with primary GBM. However, they correlated this finding to the younger age of cases with secondary GBMs than as a reflection of different biologic behavior [14]. Many studies have emphasized the importance of age as a factor influencing survival in patients with glioblastoma, but a unique finding in our study was that for this population analysis there was a survival advantage for younger age by 10 -year increments and also when examining age as a continuous variable.

Race as a factor in affecting the survival of patients with GBM has been studied in the past. The most striking finding in our study was that the Asian/Pacific Islanders had a significantly superior survival (hazard ratio 0.83; 95\% CI, 0.78 to $0.79 ; P=<0.001$ ) when compared to the White 
Table 3 Numbers of patients with GBM aged $<\mathbf{5 0}$ by racial groups, diagnosis year groups, and 10-year age-bands

\begin{tabular}{|c|c|c|c|c|c|}
\hline \multirow[b]{2}{*}{ Racial Groups } & \multirow[b]{2}{*}{$\begin{array}{l}\text { Diagnosis } \\
\text { Year Groups }\end{array}$} & \multicolumn{3}{|c|}{ 10-Year Age-Bands } & \multirow[b]{2}{*}{ Total } \\
\hline & & 20 to 29 & 30 to 39 & 40 to 49 & \\
\hline \multirow[t]{4}{*}{ White } & 1973 to 1979 & 90 & 134 & 318 & 542 \\
\hline & 1980 to 1989 & 86 & 190 & 401 & 677 \\
\hline & 1990 to 1999 & 117 & 312 & 797 & 1,226 \\
\hline & 2000 to 2008 & 231 & 551 & 1,852 & 2,634 \\
\hline White Total & & 524 & 1,187 & 3,368 & 5,079 \\
\hline \multirow[t]{4}{*}{ Black } & 1973 to 1979 & 7 & 8 & 11 & 26 \\
\hline & 1980 to 1989 & 6 & 18 & 35 & 59 \\
\hline & 1990 to 1999 & 9 & 19 & 55 & 83 \\
\hline & 2000 to 2008 & 20 & 29 & 130 & 179 \\
\hline Black Total & & 42 & 74 & 231 & 347 \\
\hline \multirow{4}{*}{$\begin{array}{l}\text { Asian/ } \\
\text { Pacific Islander }\end{array}$} & 1973 to 1979 & 4 & 3 & 7 & 14 \\
\hline & 1980 to 1989 & 1 & 7 & 15 & 23 \\
\hline & 1990 to 1999 & 10 & 28 & 42 & 80 \\
\hline & 2000 to 2008 & 20 & 33 & 101 & 154 \\
\hline $\begin{array}{l}\text { Asian/Pacific } \\
\text { Islander Total }\end{array}$ & & 35 & 71 & 165 & 271 \\
\hline \multirow{4}{*}{$\begin{array}{l}\text { American Indian/ } \\
\text { Alaska Native }\end{array}$} & 1973 to 1979 & - & - & - & - \\
\hline & 1980 to 1989 & - & - & - & \\
\hline & 1990 to 1999 & & 3 & 3 & 6 \\
\hline & 2000 to 2008 & 2 & 3 & 12 & 17 \\
\hline $\begin{array}{l}\text { American Indian/ } \\
\text { Alaska Native Total }\end{array}$ & & 2 & 6 & 15 & 23 \\
\hline \multirow[t]{4}{*}{ Unknown } & 1973 to 1979 & - & - & - & - \\
\hline & 1980 to 1989 & - & - & 2 & 2 \\
\hline & 1990 to 1999 & 1 & 1 & 1 & 3 \\
\hline & 2000 to 2008 & - & 3 & 2 & 5 \\
\hline Unknown Total & & 1 & 4 & 5 & 10 \\
\hline \multirow[t]{4}{*}{ Other } & 1973 to 1979 & - & - & - & - \\
\hline & 1980 to 1989 & - & - & - & - \\
\hline & 1990 to 1999 & - & - & - & - \\
\hline & 2000 to 2008 & - & - & 2 & 2 \\
\hline Other Total & & - & - & 2 & 2 \\
\hline \multirow[t]{4}{*}{ All Races } & 1973 to 1979 & 101 & 145 & 336 & 582 \\
\hline & 1980 to 1989 & 93 & 215 & 453 & 761 \\
\hline & 1990 to 1999 & 137 & 363 & 898 & 1,398 \\
\hline & 2000 to 2008 & 273 & 619 & 2,099 & 2,991 \\
\hline All Races Total & & 604 & 1,342 & 3,786 & 5,732 \\
\hline
\end{tabular}

population. These data correlate with the study done by Barnholtz-Sloan et al. [2]. Between 1991and 1999, they studied 1,530 patients in the SEER database diagnosed with glioblastoma aged greater than 65 years of age with the intention to analyze racial differences in survival. A significant racial difference in survival was seen in the Asian population when compared to white, black and other populations. Robertson et al. [15] studied the incidence of glioblastoma, astrocytoma and oligodendroglioma in the white and black population in the Memphis Statistical Metropolitan area during the 1984 to 1994 period. This study did not include the Asian race, but confirmed that there were no significant differences in survival between the white and black populations despite disparity in the incidence rates. Our results confirm that racial differences in survival exist in patients diagnosed with glioblastoma, with the Asian race having increased survival when compared to other races. The reasons for this are not clearly defined. Small studies have suggested that genetic and molecular differences may play a role. There may be a higher incidence of primary glioblastomas overexpressing p 53 (Protein 53 or tumor protein 53) and PDGFR-alpha (Platelet Derived Growth Factor Receptor) similar to secondary glioblastomas in Asians [16]. However, other unknown molecular and biologic factors may play a role and this needs to be further investigated.

The management of glioblastoma has progressively changed and evolved over the course of the last two decades with new developments in technology to help with diagnosis, novel radiation techniques and advances in surgical procedures [17]. Not surprisingly, several studies have shown an improvement in outcomes over the last decade $[10,18,19]$. An interesting finding in our study was that the patients who were diagnosed with glioblastoma during the years 2000 to 2008 had a significantly improved survival (hazard ratio $0.78 ; 95 \% \mathrm{CI}, 0.74$ to $0.81 ; P=<0.001$ ) when compared to other groups. The second group (1980 to 1989 ) with a hazard ratio of 0.93 (95\% CI, 0.88 to 0.98 ; $P=0.005)$ and the third group (1990 to 1999) with a hazard ratio of $0.93(95 \% \mathrm{CI}, 0.89$ to $0.98 ; P=0.005)$ also showed improved survival when compared to the reference group. Our study shows a gradual increase in median survival in patients diagnosed with glioblastoma from the year 1973 to the year 2008. This could be related to the ever-changing patterns of care, and improvement in supportive care as well as improved radiation and surgical treatments being administered to these patients. Koshy et al. [19] recently reported a study involving patients diagnosed with GBM who underwent surgery and post-operative RT. These patients were selected from the Surveillance, Epidemiology and End Results database and grouped into time periods: 2000 to 2001, 2002 to 2003,2004 and 2005 to 2006 based on year of diagnosis. They concluded that patients diagnosed in 2005 to 2006 had significantly improved survival when compared to patients diagnosed in 2000 to 2001 ( $\mathrm{HR}=0.648,95 \% \mathrm{CI}$ 0.604 to 0.696$)$. This finding is consistent with our findings. With the advent of novel chemotherapeutic drugs, improved radiation techniques (including 3-D conformation 
Table 4 Numbers of patients with GBM aged $<\mathbf{5 0}$ by radiation treatment groups, extent of surgery groups, and 10-year age-bands

\begin{tabular}{|c|c|c|c|c|c|}
\hline & & \multirow[b]{2}{*}{20 to 29} & \multicolumn{2}{|c|}{ 10-Year Age-Bands } & \multirow[b]{2}{*}{ Total } \\
\hline & & & 30 to 39 & 40 to 49 & \\
\hline Radiation Groups & Extent of Surgery Groups & & & & \\
\hline \multirow[t]{3}{*}{ Yes } & Surgical Resection & 378 & 911 & 2,549 & 18,054 \\
\hline & No Cancer Directed Resection & 64 & 111 & 373 & 4,312 \\
\hline & Unknown & 22 & 41 & 96 & 1,020 \\
\hline Yes Total & & 464 & 1,063 & 3,018 & 23,386 \\
\hline \multirow[t]{3}{*}{ No } & Surgical Resection & 78 & 152 & 424 & 5,152 \\
\hline & No Cancer Directed Resection & 34 & 64 & 199 & 4,085 \\
\hline & Unknown & 12 & 26 & 54 & 937 \\
\hline No Total & & 124 & 242 & 677 & 10,174 \\
\hline \multirow[t]{3}{*}{ Unknown } & Surgical Resection & 6 & 28 & 57 & 596 \\
\hline & No Cancer Directed Resection & 4 & 3 & 12 & 214 \\
\hline & Unknown & 6 & 6 & 22 & 294 \\
\hline Unknown Total & & 16 & 37 & 91 & 1,104 \\
\hline \multirow[t]{3}{*}{ All Radiation Groups } & Surgical Resection & 462 & 1,091 & 3,030 & 4,583 \\
\hline & No Cancer Directed Resection & 102 & 178 & 584 & 864 \\
\hline & Unknown & 40 & 73 & 172 & 285 \\
\hline All Radiation Groups Total & & 604 & 1,342 & 3,786 & 5,732 \\
\hline
\end{tabular}

radiation, intensity modulated radiotherapy (IMRT), and stereotactic radiosurgery (SRS)), advanced surgical techniques, and a better understanding of molecular biology, the median survival could be expected to increase further in the coming years. In fact, several recent studies have reported an increased number of long term survivors [20-26]. Scoccianti et al. studied 1,059 patients treated in 18 radiotherapy centers in Italy between 2002 and 2007 and clinical, pathological, therapeutic and survival data regarding these patients were collected and retrospectively reviewed. They reported a significant difference in survival in these patients compared to patients treated between 1997 and 2001 and attributed it to a significantly increased frequency of MRI imaging, increasing use of surgery as opposed to biopsy and use of 3-D conformal radiotherapy and temozolamide [27].

Surgical resection done after the primary diagnosis can prolong the survival, allow more comprehensive histological diagnosis and can provide relief from neurologic deficits related to the mass effect. Our study results are consistent with results of other studies [5,28]. When compared to the "Surgical Resection" group, the "No Cancer Related Resection" group showed a significantly decreased survival. This marked difference in survival emphasizes the importance of surgical resection, and also how the extent of surgical resection plays a role in prolonging the survival in patients with glioblastoma. Filippini et al. reported a significant difference in survival in patients who had undergone surgical resection vs patients who underwent only biopsy [29]. The hazard ratio for death in patients who had undergone surgical resection versus those who had undergone biopsy only was 0.55 (95\% CI, 0.42 to $0.72 ; P=<0.001$ ), a $45 \%$ relative reduction in the risk of death or an eight-month increase in median survival time. Gross total resection/ extensive resection of the tumor at the time of initial diagnosis was associated with statistically significant increased survival when compared to sub-total resection/partial resection $[29,30]$. Patients older than 65 to 75 years of age, unlike younger patients, are often not offered aggressive surgery because of their age, associated comorbidities and the potential inability to tolerate surgery. In a recent study reported by Oszvald et al., the overall survival of older patients aged greater than 65 years $(9.1 \pm 11.6$ months) was significantly lower than that of younger patients $(14.9 \pm 16.7$ months; $P=0.0001)$ [31]. However, age was a negative prognostic factor in patients undergoing biopsy $(4.0 \pm 7.1$ vs $7.9 \pm 8.7$ months; $P=0.007)$, but not in patients undergoing tumor resection $(13.0 \pm 8.5$ vs $13.3 \pm 14.5$ months; $P=0.86)$. Survival of older patients undergoing complete tumor resection was $17.7 \pm 8.1$ months and compared favorably with younger patients emphasizing the importance of surgery.

Radiation therapy remains the post-operative backbone in the management of patients with glioblastoma. Our study confirms the importance of radiation treatment in prolonging the survival of patients with glioblastoma. 


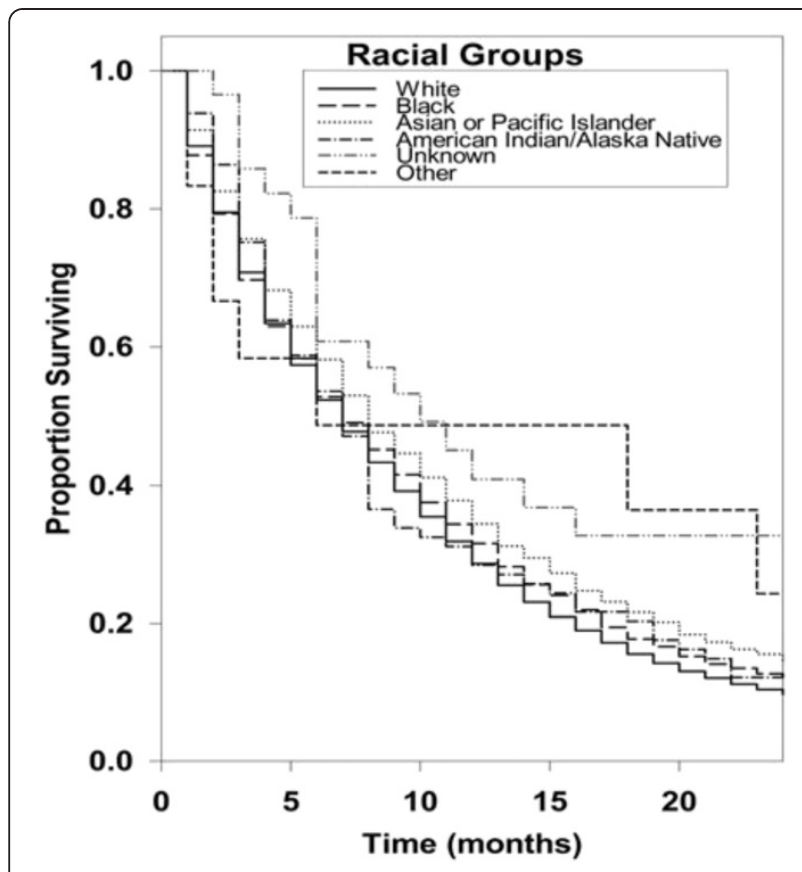

Figure 1 Survival curves of patients with GBM by racial group.

Both the "No radiation" group (hazard ratio 3.45; 95\% CI, 3.33 to $3.45 ; P=/<0.001$ ) and the "Unknown radiation" group (hazard ratio 2.50; 95\% CI, 2.33 to 2.70; $P=/<0.001$ ) showed a marked decreased survival when

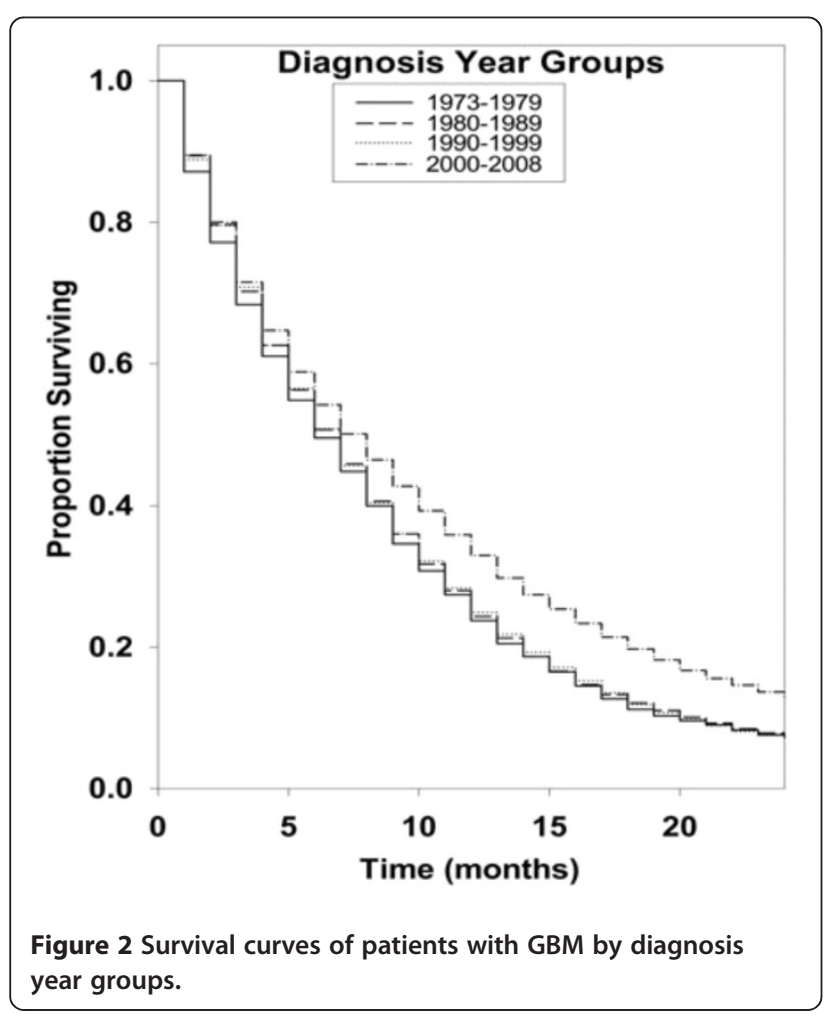

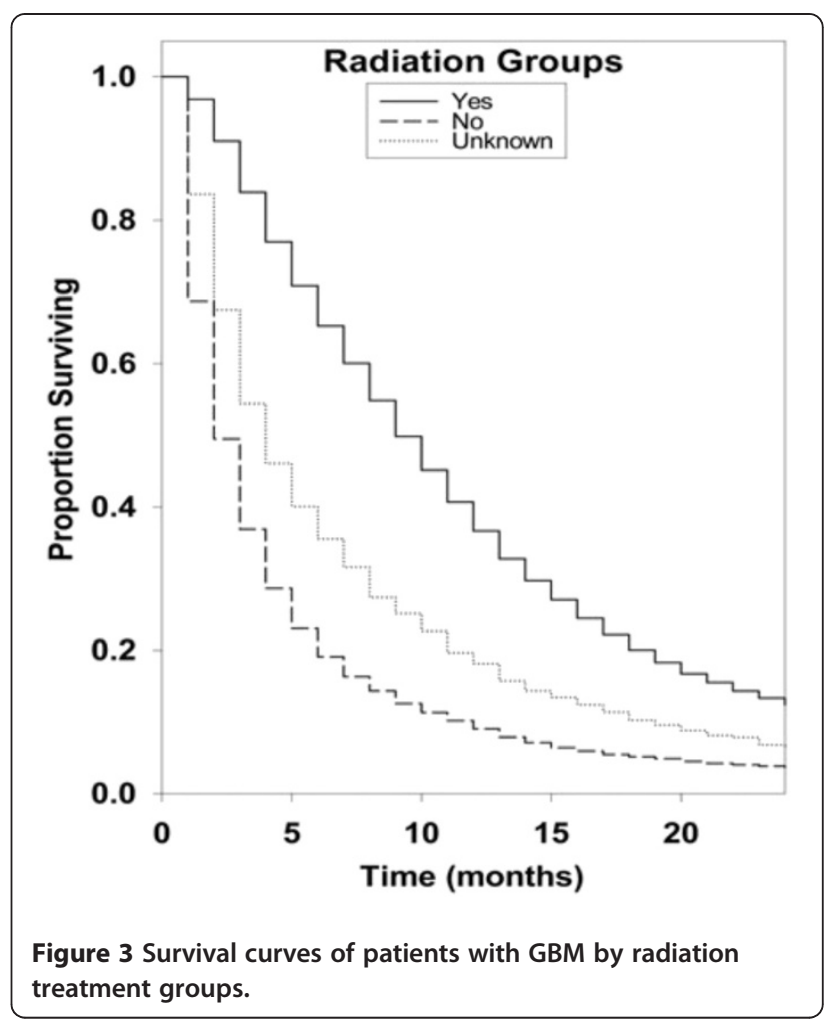

compared to the "Yes radiation" group of patients. Studies by Filippini et al. have shown that radiotherapy in glioblastoma patients can increase survival, with a one-

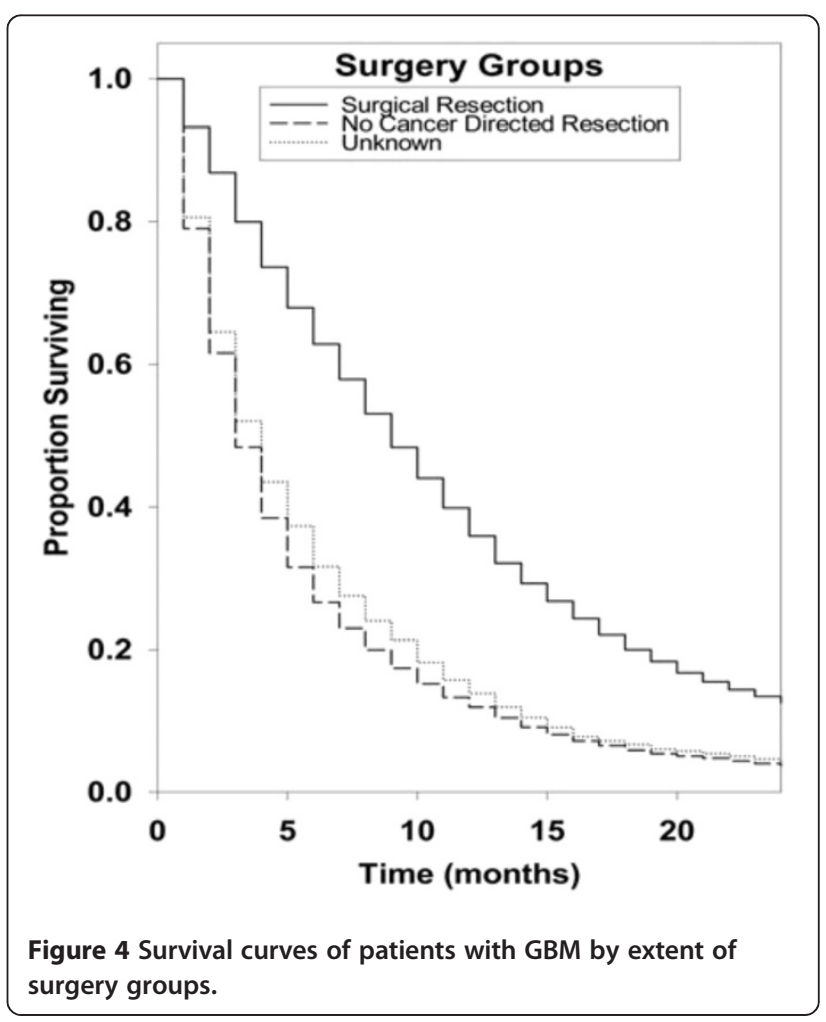




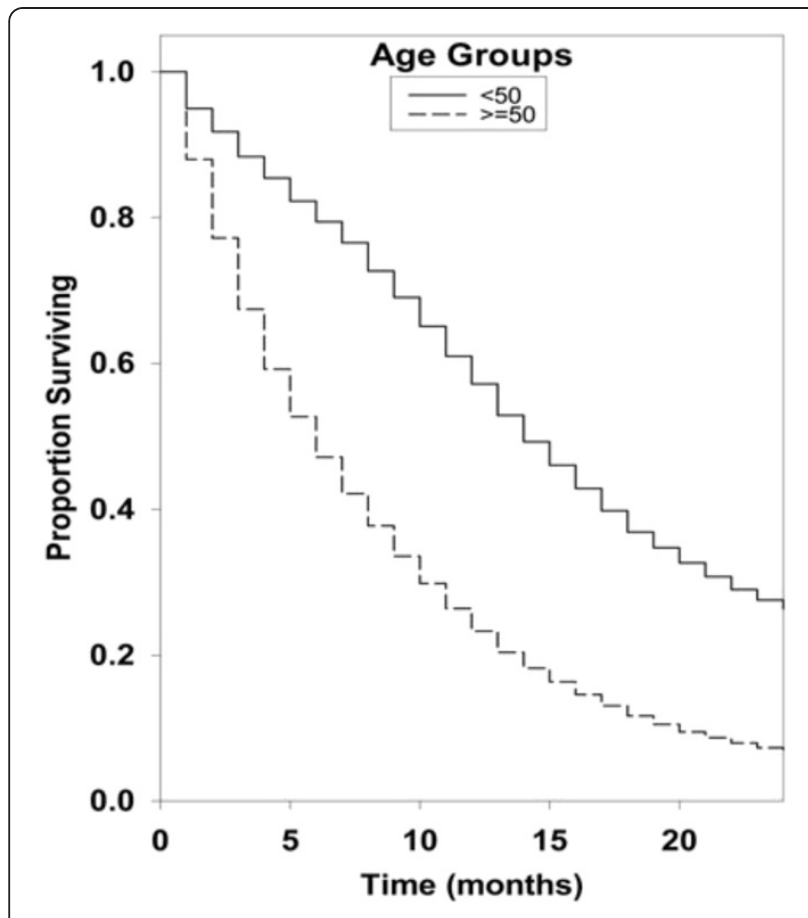

Figure 5 Survival curves of patients with GBM by age groups.

third (hazard ratio $0.61 ; 95 \% \mathrm{CI}, 0.45$ to $0.83 ; P=.001$ ) reduction in relative risk of dying [29]. Substantial research is underway to develop methods for enhancing

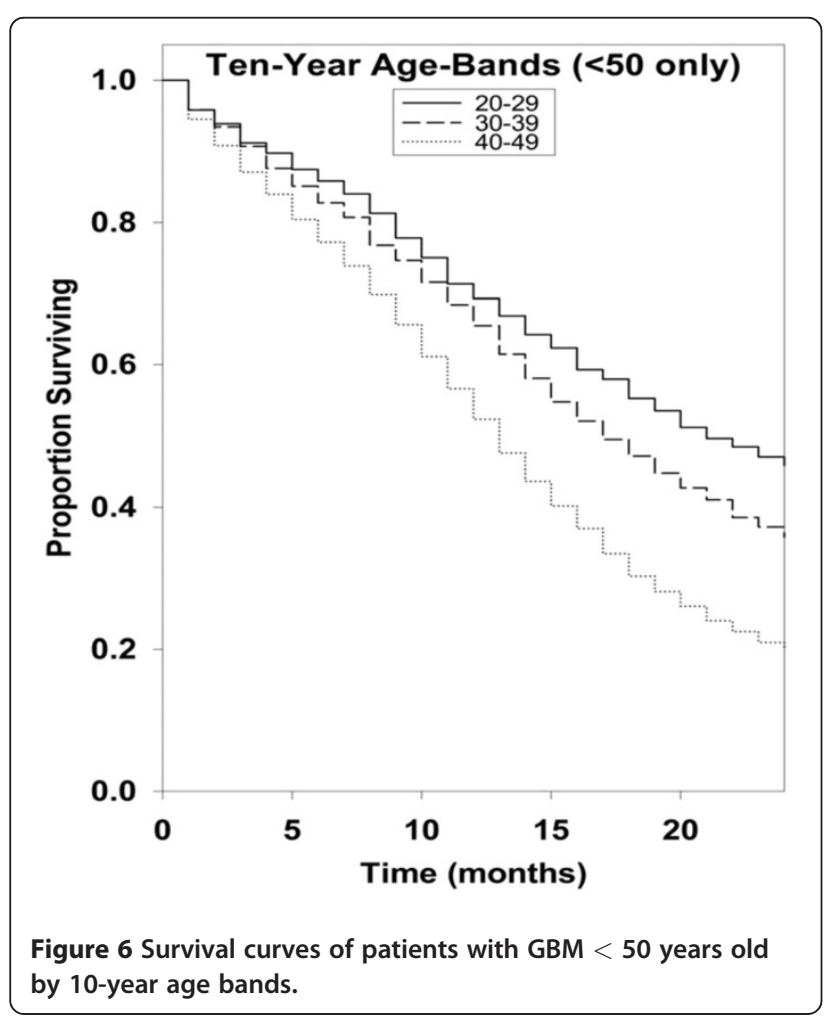

Table 5 Univariate median survival estimates (months) and hazard ratios of patients with GBM by racial groups, diagnosis year groups, and age groups

\begin{tabular}{|c|c|c|c|c|c|}
\hline & \multicolumn{2}{|c|}{ Median Survival } & \multicolumn{3}{|c|}{ Hazard Ratio } \\
\hline & & $95 \% \mathrm{Cl}$ & Estimate & $95 \% \mathrm{Cl}$ & $P$-value** \\
\hline \multicolumn{6}{|l|}{ Racial Groups } \\
\hline White* & 31,820 & $6 \pm 0.11$ & reference & & \\
\hline Black & 1,526 & $6 \pm 0.61$ & 0.95 & 0.89 to 1.00 & 0.066 \\
\hline $\begin{array}{l}\text { Asian/Pacific } \\
\text { Islander }\end{array}$ & 1,177 & $8 \pm 0.67$ & 0.83 & 0.78 to 0.89 & $<0.001$ \\
\hline $\begin{array}{l}\text { American Indian/ } \\
\text { Alaskan Native }\end{array}$ & 87 & $6 \pm 2.03$ & 0.86 & 0.68 to 1.10 & 0.237 \\
\hline Unknown & 39 & $9 \pm 6.10$ & 0.59 & 0.37 to 0.88 & 0.009 \\
\hline Other & 15 & $6 \pm 19.91$ & 0.75 & 0.35 to 1.43 & 0.467 \\
\hline \multicolumn{6}{|c|}{ Diagnosis Year Groups } \\
\hline 1973 to $1979^{*}$ & 2,836 & $5 \pm 0.35$ & reference & & \\
\hline 1980 to 1989 & 4,528 & $6 \pm 0.28$ & 0.93 & 0.88 to 0.98 & 0.005 \\
\hline 1990 to 1999 & 8,265 & $6 \pm 0.20$ & 0.93 & 0.89 to 0.98 & 0.005 \\
\hline 2000 to 2008 & 19,035 & $7 \pm 0.18$ & 0.78 & 0.74 to 0.81 & $<0.001$ \\
\hline
\end{tabular}

\section{Radiation Treatment Groups}

$\begin{array}{lccccc}\text { Yes* }^{*} & 23,386 & 9 \pm 0.13 & \text { reference } & & \\ \text { No } & 10,174 & 2 \pm 0.06 & 3.45 & 3.33 \text { to } 3.45 & <0.001 \\ \text { Unknown } & 1,104 & 3 \pm 0.26 & 2.50 & 2.33 \text { to } 2.70 & <0.001\end{array}$

\section{Extent of Surgery Groups}

Surgical Resection* 23,802 $9 \pm 0.14$ reference

$\begin{array}{lrrrrr}\text { No Cancer } & 8,611 & 3 \pm 0.09 & 2.38 & 2.33 \text { to } 2.44 & <0.001 \\ \text { Directed Resection } & & & & & \\ \text { Unknown } & 2,251 & 3 \pm 0.18 & 0.96 & 0.93 \text { to } 1.00 & 0.126\end{array}$

Age (Continuous Variable)

$\begin{array}{lllll}\text { Age } & 34,664 & 1.037 & 1.036 \text { to } 1.038<0.001\end{array}$

\section{Age Groups}

$\begin{array}{lrllll}<50^{*} & 5,732 & 14 \pm 0.37 & \text { reference } & & \\ >=50 & 28,932 & 5 \pm 0.10 & 2.22 & 2.17 \text { to } 2.33 & <0.001\end{array}$

Ten-Year Age-Bands ( $<\mathbf{5 0}$ only)

\begin{tabular}{|c|c|c|c|c|}
\hline 20 to $29^{*}$ & 604 & $20 \pm 2.37$ reference & & \\
\hline 30 to 39 & 1,342 & $16 \pm 1.051 .23$ & 1.10 to 1.39 & $<0.001$ \\
\hline 40 to 49 & 3,786 & $12 \pm 0.391 .85$ & 1.67 to 2.04 & $<0.001$ \\
\hline
\end{tabular}

the radio-sensitivity of GBM as most patients relapse after initial response. Tumor tissue hypoxia has been reported as an important mechanism involving tumor resistance to radiation, and using substances that can increase tumor sensitivity to radiation (radiosensitizers) is being recommended [32]. In the landmark randomized study, Stupp et al. reported that delivery of temozolamide during radiotherapy increased survival, suggesting that this DNA alkylating agent can increase survival by enhancing radiosensitivity of GBM cells. This study 
Table 6 Univariate 1-, 2-, and 5-year absolute survival rates of patients with GBM by racial groups, diagnosis year groups, radiation treatment groups, extent of surgery groups, and age groups

\begin{tabular}{|c|c|c|c|c|c|c|c|c|c|}
\hline & 1-year & $95 \% \mathrm{Cl}$ & & 2-year & $95 \% \mathrm{Cl}$ & & 5-year & $95 \% \mathrm{Cl}$ & \\
\hline \multicolumn{10}{|l|}{ Racial Groups } \\
\hline White* & 30.54 & $30.03-31.05$ & & 10.11 & $9.76-10.46$ & & 3.25 & $3.02-3.48$ & \\
\hline Black & 32.42 & $30.06-34.80$ & & 12.10 & $10.44-13.88$ & & 3.31 & $2.34-4.55$ & \\
\hline Asian/Pacific Islander & 36.79 & $33.99-39.59$ & ** & 15.17 & $13.04-17.44$ & $* *$ & 5.30 & $3.89-7.02$ & ** \\
\hline Am. Indian/Alaskan & 29.41 & $20.16-39.26$ & & 11.51 & $5.71-19.54$ & & 8.12 & $3.22-15.97$ & \\
\hline Unknown & 47.06 & $29.83-62.52$ & & 32.20 & $15.30-50.09$ & $* *$ & 18.40 & $4.95-38.54$ & ** \\
\hline Other & 53.85 & $24.77-75.99$ & & 29.91 & $6.78-58.20$ & & & insufficient data & \\
\hline \multicolumn{10}{|l|}{ Diagnosis Year Groups } \\
\hline 1973 to $1979^{*}$ & 24.79 & $23.21-26.39$ & & 6.86 & $5.97-7.83$ & & 2.30 & $1.79-2.90$ & \\
\hline 1980 to 1989 & 26.39 & $25.12-27.69$ & & 7.36 & $6.62-8.14$ & & 2.41 & $1.99-2.89$ & \\
\hline 1990 to 1999 & 26.77 & $25.82-27.73$ & & 7.11 & $6.56-7.67$ & & 2.18 & $1.88-2.52$ & \\
\hline 2000 to 2008 & 34.75 & $34.06-35.44$ & $* *$ & 13.45 & $12.93-13.98$ & $* *$ & 4.37 & $3.99-4.77$ & ** \\
\hline \multicolumn{10}{|l|}{ Radiation Treatment Groups } \\
\hline Yes* $^{*}$ & 41.12 & $40.48-41.75$ & & 13.68 & $13.22-14.15$ & & 4.13 & $3.83-4.44$ & \\
\hline No & 9.25 & $8.70-9.83$ & ** & 3.50 & $3.13-3.89$ & ** & 1.74 & $1.46-2.05$ & ** \\
\hline Unknown & 15.69 & $13.60-17.91$ & $* *$ & 5.43 & $4.15-6.95$ & $* *$ & 2.10 & $1.28-3.26$ & ** \\
\hline \multicolumn{10}{|l|}{ Extent of Surgery Groups } \\
\hline Surgical Resection* & 39.21 & $38.58-39.84$ & & 13.39 & $12.93-13.85$ & & 4.23 & $3.94-4.55$ & \\
\hline No Cancer Directed Resection & 12.78 & $12.08-13.50$ & $* *$ & 3.92 & $3.49-4.37$ & $* *$ & 1.44 & $1.16-1.76$ & ** \\
\hline Unknown & 12.83 & $11.48-14.24$ & $* *$ & 3.78 & $3.05-4.63$ & ** & 1.35 & $0.93-1.90$ & ** \\
\hline \multicolumn{10}{|l|}{ Age Groups } \\
\hline$<50^{*}$ & 58.32 & $57.01-59.60$ & & 26.56 & $25.37-27.76$ & & 11.12 & $10.22-12.05$ & \\
\hline$>=50$ & 25.46 & $24.95-25.97$ & $* *$ & 7.14 & $6.83-7.46$ & $* *$ & 1.67 & $1.49-1.87$ & ** \\
\hline \multicolumn{10}{|l|}{ Ten-Year Age-Bands ( $<50$ only) } \\
\hline 20 to $29^{*}$ & 68.17 & $64.24-71.77$ & & 44.90 & $40.74-48.96$ & & 23.09 & $19.48-26.89$ & \\
\hline 30 to 39 & 65.31 & $62.66-67.83$ & & 35.55 & $32.89-38.21$ & ** & 16.73 & $14.60-18.98$ & ** \\
\hline 40 to 49 & 54.26 & $52.63-55.85$ & $* *$ & 20.38 & $19.05-21.75$ & $* *$ & 7.09 & $6.19-8.07$ & ** \\
\hline
\end{tabular}

* Reference group against which other groups' survival experience are compared.

** Statistically significant result $(P<0.025)$ comparing whether groups' survival rate is the same as reference group.

reported the overall survival rates with radiation and temozolamide to be $27.2 \%$ at two years, $16.0 \%$ at three years, $12.1 \%$ at four years and $9.8 \%$ at five years [33]. SRS is being increasingly used to treat recurrent tumors because it can target any area of the brain with extreme accuracy, thereby minimizing the effect of radiation on the adjacent brain tissue and the critical structures nearby. SRS can be used multiple times in select situations and also can be used to treat multiple sites of recurrences in the same treatment setting. Recent studies have shown that re-irradiation with stereotactic radiosurgery for recurrent glioblastoma is a very effective and feasible method of improving survival [34,35].

The complex molecular and biologic factors leading to the development of glioblastomas are beginning to be unraveled and our understanding of molecular pathogenesis has increased significantly in the last two decades. Glioblastomas are a heterogeneous group of tumors and likely arise as a result of multiple genetic alterations, including activation of oncogenes, inactivation of tumor suppressor genes or deregulation of DNA repair genes or other mechanisms [36]. Abnormal expression of tumor suppressor genes tp 53 or p 53 (tumor protein 53), PTEN (phosphatase and tensin homolog) and $\mathrm{mdm} 2$ (murine double minute oncogene) an important negative regulator of p53 have been implicated in the pathogenesis of GBM. Karyotyping has revealed multiple other abnormalities with significant differences between primary and secondary glioblastomas (GBM that arises as a result of transformation of lower grade gliomas). Trisomy 7, monosomy 10, allelic loss of $17 \mathrm{p}$, epidermal growth factor receptor gene (EGFR) amplification are some of the other abnormalities that have been identified. TP 53 mutations are more frequent in 
Table 7 Multivariate hazard ratios, confidence intervals, and $P$-values of patients with GBM by racial groups, diagnosis year groups, and age

\begin{tabular}{|c|c|c|c|}
\hline & \multicolumn{3}{|c|}{ Hazard Ratio } \\
\hline & Estimate & $95 \% \mathrm{Cl}$ & $P$ value ${ }^{* *}$ \\
\hline \multicolumn{4}{|l|}{ Racial Groups } \\
\hline White ${ }^{*}$ & reference & & \\
\hline Black & 0.97 & 0.91 to 1.02 & 0.238 \\
\hline Asian/Pacific Islander & 0.89 & 0.83 to 0.95 & $<0.001$ \\
\hline American Indian/Alaska Native & 0.87 & 0.69 to 1.10 & 0.230 \\
\hline Unknown & 0.51 & 0.33 to 0.78 & 0.002 \\
\hline Other & 0.91 & 0.49 to 1.69 & 0.764 \\
\hline \multicolumn{4}{|l|}{ Diagnosis Year Groups } \\
\hline 1973 to $1979^{*}$ & reference & & \\
\hline 1980 to 1989 & 0.88 & 0.87 to 0.89 & $<0.001$ \\
\hline 1990 to 1999 & 0.80 & 0.78 to 0.81 & $<0.001$ \\
\hline 2000 to 2008 & 0.65 & 0.62 to 0.68 & $<0.001$ \\
\hline \multicolumn{4}{|l|}{ Radiation Treatment Groups } \\
\hline Yes* $^{*}$ & reference & & \\
\hline No & 2.00 & 1.95 to 2.06 & $<0.001$ \\
\hline Unknown & 1.59 & 1.48 to 1.70 & $<0.001$ \\
\hline \multicolumn{4}{|l|}{ Extent of Surgery Groups } \\
\hline Surgical Resection* & reference & & \\
\hline No Cancer Directed Resection & 1.64 & 1.59 to 1.69 & $<0.001$ \\
\hline Unknown & 1.27 & 1.20 to 1.34 & $<0.001$ \\
\hline \multicolumn{4}{|l|}{ Age (Continuous Variable) } \\
\hline Age & 1.031 & 1.030 to 1.032 & $<0.001$ \\
\hline
\end{tabular}

* Reference group against which other groups' survival experience are compared.

secondary GBMs and generally do not coexist with EGFR gene amplification [37]. Secondary GBMs are associated with better outcomes compared to primary GBM [14]. Recently, other biologic factors have been reported that have been associated with favorable outcomes. Sano et al. [38] noted a statistically significant improved prognosis for patients with glioblastoma multiforme whose tumors expressed high levels of PTEN messenger RNA. Burton et al. analyzed tumors from 41 patients with GBM that survived 3 years or longer and compared them with 48 patients that survived less than 1.5 years for p53 aberrations (expression/mutation), epidermal growth factor receptor overexpression, mdm2 overexpression and proliferation index. Long-term survivors were significantly more likely to overexpress p53 (although a difference in p53 mutation rate was not observed) and significantly less likely to exhibit mdm2 overexpression, and had a significantly lower proliferation rate compared with typical GBM survivors [4]. Deletion of NFKBIA (encoding nuclear factor of $\kappa$-light polypeptide gene enhancer in B-cells inhibitor- $\alpha$ ), an inhibitor of the EGFR-signaling pathway, promotes tumorigenesis in glioblastomas that do not have alterations of EGFR and is associated with a poor prognosis [39].

There is growing evidence that expression of $\mathrm{O}$ (6)methylguanine-DNA methyltransferase (MGMT), a DNA repair enzyme that causes resistance to alkylating agents plays an important role in the pathogeneisis of glioma. Promoter methylation of MGMT leads to epigenetic silencing of the MGMT and this compromises DNA repair and has been associated with improved outcomes in patients with glioblastoma who receive alkylating agents. There is also evidence that MGMT hypermethylation and low or absent expression are frequent in oligodendroglial tumors and likely contribute to the chemosensitivity and improved outcomes of these tumors. Wiencke et al. reported that younger age was associated with increased incidence of TP 53 mutation and it is possible that this may be directly or indirectly related to better outcomes related to young age [40]. They also reported similar findings of increased TP 53 mutations in African Americans and Asians compared to Whites. Several studies have found an inverse relationship between glioma risk and atopy or allergy history and this is an area of ongoing research [41]. It is possible that some of these and other unknown molecular differences are associated with improved outcomes related to age, race and treatment, and future research should look into the molecular heterogeneity between different prognostic subgroups of patients.

\section{Conclusions}

In conclusion, to our knowledge this is the largest reported population analysis in the world literature of patient survival outcomes with glioblastoma. For a patient with glioblastoma, variables predicting longer survival include younger age ( $<50$ years), race of the patient (Asian race being favorable), surgical excision of the tumor (gross total resection preferred), and adjuvant radiation treatment. Also, addition of temozolamide to local treatment improves survival based on randomized studies. Our study did not include assessment of chemotherapy as a prognostic variable since details regarding this were not available in the SEER database. Future research should explore the biologic differences between different prognostic subgroups of patients. With this near universally fatal disease, any small breakthrough will have a significant impact on survival and provide hope to the thousands of patients who receive this diagnosis annually. Also, the continued individualization of treatment for each unique patient's situation will allow for improvements in survival as well as quality of life.

\section{Abbreviations}

CNS: Central nervous system; EGFR: Epidermal growth factor receptor; GBM: Glioblastoma multiforme; IMRT: intensity modulated radiotherapy; 
KPS: Karnofsky performance status; mdm2: Murine double minute oncoogene; MGMT: Methylguanine-DNA methyltransferase; NCl: National Cancer Institute; p53: Protein 53 or tumor protein 53; PDGFR: Platelet Derived Growth Factor Receptor; PTEN: Phosphatase and tensin homolog; RT: radiotherapy; SEER: Surveillance, Epidemiology, and End Results; SRS: Stereotactic radiosurgery.

\section{Competing interests}

The authors of this manuscript have no conflicts of interests, ethical conflicts or financial disclosures to make regarding this paper.

\section{Acknowledgements}

We would like to acknowledge Eric Reynolds, Rachel Garman and Jill Adams, as well as the entire Gamma Knife of Spokane and Cancer Care Northwest research staff for their contributions to this manuscript. The full statistical analysis was performed by Ben Perissini, MS (DataWorks Northwest, LLC).

\section{Author details}

${ }^{1}$ The Gamma Knife of Spokane, Spokane, WA, USA. ${ }^{2}$ Cancer Care Northwest, Spokane, WA, USA. ${ }^{3}$ Mackay \& Meyer MDs, Spokane, WA, USA. ${ }^{4}$ Spokane Brain \& Spine, Spokane, WA, USA. ${ }^{5}$ Gamma Knife of Spokane and Cancer Care Northwest, Deaconess Health and Education Building, 910 West 5th Ave, Suite 102, Spokane, WA 99204, USA.

\section{Authors' contributions}

SRT and CML reviewed relevant literature and drafted the manuscript. BJP conducted all statistical analyses. RKF, WTL, ARM, JJD, BSC, ALE and PWH provided clinical expertise and participated in drafting the manuscript. All authors read and approved the final manuscript.

\section{Funding}

No funding was utilized for this project.

Received: 22 December 2011 Accepted: 3 May 2012

Published: 3 May 2012

\section{References}

1. Stupp R, Mason WP, van den Bent MJ, Weller M, Fisher B, Taphoorn MJ, Belanger K, Brandes AA, Marosi C, Bogdahn U, Curschmann J, Janzer RC, Ludwin SK, Gorlia T, Allgeier A, Lacombe D, Cairncross JG, Eisenhauer E, Mirimanoff RO, European Organisation for Research and Treatment of Cancer Brain Tumor and Radiotherapy Groups, National Cancer Institute of Canada Clinical Trials Group: Radiotherapy plus concomitant and adjuvant temozolomide for glioblastoma. N Engl J Med 2005, 352:987-996.

2. Barnholtz-Sloan JS, Maldonado JL, Williams VL, Curry WT, Rodkey EA, Barker FG 2nd, Sloan AE: Racial/ethnic differences in survival among older patients with a primary glioblastoma. J Neurooncol 2007, 85:171-180

3. Siker ML, Wang M, Porter K, Nelson DF, Curran WJ, Michalski JM, Souhami L, Chakravarti A, Yung WK, Delrowe J, Coughlin CT, Mehta MP: Age as an independent prognostic factor in patients with glioblastoma: a Radiation Therapy Oncology Group and American College of Surgeons National Cancer Data Base comparison. J Neurooncol 2011, 104:351-356.

4. Burton EC, Lamborn KR, Forsyth P, Scott J, O'Campo J, Uyehara-Lock J, Prados M, Berger M, Passe S, Uhm J, O'Neill BP, Jenkins RB, Aldape KD: Aberrant p53, mdm2, and proliferation differ in glioblastomas from longterm compared with typical survivors. Clin Cancer Res 2002, 8:180-187.

5. Kuhnt D, Becker A, Ganslandt O, Bauer M, Buchfelder M, Nimsky C: Correlation of the extent of tumor volume resection and patient survival in surgery of glioblastoma multiforme with high-field intraoperative MRI guidance. Neuro Oncol 2011, 13:1339-1348.

6. Curran WJ Jr, Scott CB, Horton J, Nelson JS, Weinstein AS, Fischbach AJ, Chang $\mathrm{CH}$, Rotman M, Asbell SO, Krisch RE, et al: Recursive partitioning analysis of prognostic factors in three Radiation Therapy Oncology Group malignant glioma trials. J Natl Cancer Inst 1993, 85:704-710.

7. Lacroix M, Abi-Said D, Fourney DR, Gokaslan ZL, Shi W, DeMonte F, Lang FF, McCutcheon IE, Hassenbusch SJ, Holland E, Hess K, Michael C, Miller D, Sawaya R: A multivariate analysis of 416 patients with glioblastoma multiforme: prognosis, extent of resection, and survival. J Neurosurg 2001, 95:190-198.

8. Erpolat OP, Akmansu M, Goksel F, Bora H, Yaman E, Buyukberber S: Outcome of newly diagnosed glioblastoma patients treated by radiotherapy plus concomitant and adjuvant temozolomide: a long-term analysis. Tumori 2009, 95:191-197.

9. Naydenov E, Tzekov C, Minkin K, Nachev S, Romansky K, Bussarsky V: Longterm survival with primary glioblastoma multiforme: a clinical study in bulgarian patients. Case Rep Oncol 2011, 4:1-11.

10. Darefsky AS, King JT Jr, Dubrow R: Adult glioblastoma multiforme survival in the temozolomide era: a population-based analysis of surveillance, epidemiology, and end results registries. Cancer 2011. Epub ahead of print.

11. Chandler $\mathrm{KL}$, Prados MD, Malec M, Wilson CB: Long-term survival in patients with glioblastoma multiforme. Neurosurgery 1993, 32:716-720. discussion 720

12. Scott JN, Rewcastle NB, Brasher PM, Fulton D, MacKinnon JA, Hamilton M, Cairncross JG, Forsyth P: Which glioblastoma multiforme patient will become a long-term survivor? A population-based study. Ann Neurol 1999, 46:183-188.

13. Sneed PK, Prados MD, McDermott MW, Larson DA, Malec MK, Lamborn KR, Davis RL, Weaver KA, Wara WM, Phillips TL, et al: Large effect of age on the survival of patients with glioblastoma treated with radiotherapy and brachytherapy boost. Neurosurgery 1995, 36:898-903. discussion 903-904.

14. Ohgaki H, Dessen $P$, Jourde B, Horstmann S, Nishikawa T, Di Patre PL, Burkhard C, Schuler D, Probst-Hensch NM, Maiorka PC, Baeza N, Pisani P, Yonekawa Y, Yasargil MG, Lütolf UM, Kleihues P: Genetic pathways to glioblastoma: a population-based study. Cancer Res 2004, 64:6892-6899.

15. Robertson JT, Gunter BC, Somes GW: Racial differences in the incidence of gliomas: a retrospective study from Memphis, Tennessee. $\mathrm{Br} J$ Neurosurg 2002, 16:562-566.

16. Das A, Tan WL, Teo J, Smith DR: Glioblastoma multiforme in an Asian population: evidence for a distinct genetic pathway. J Neurooncol 2002, 60:117-125.

17. Asthagiri AR, Pouratian N, Sherman J, Ahmed G, Shaffrey ME: Advances in brain tumor surgery. Neurol Clin 2007, 25:975-1003. viii-ix.

18. Barnholtz-Sloan JS, Sloan AE, Schwartz AG: Relative survival rates and patterns of diagnosis analyzed by time period for individuals with primary malignant brain tumor, 1973-1997. J Neurosurg 2003, 99:458-466.

19. Koshy M, Villano JL, Dolecek TA, Howard A, Mahmood U, Chmura SJ, Weichselbaum RR, McCarthy BJ: Improved survival time trends for glioblastoma using the SEER 17 population-based registries. J Neurooncol 2012, 107:207-212

20. Burzynski SR, Lewy RI, Weaver R, Janicki T, Jurida G, Khan M, Larisma CB, Paszkowiak J, Szymkowski B: Long-term survival and complete response of a patient with recurrent diffuse intrinsic brain stem glioblastoma multiforme. Integr Cancer Ther 2004, 3:257-261.

21. Krex D, Klink B, Hartmann $C$, von Deimling A, Pietsch T, Simon M, Sabel M, Steinbach JP, Heese O, Reifenberger G, Weller M, Schackert G, German Glioma Network: Long-term survival with glioblastoma multiforme. Brain 2007, 130:2596-2606.

22. Nieder C, Astner ST, Molls M, Grosu AL: Analysis of long-term survivors of glioblastoma multiforme in a single institution with aggressive local retreatment protocol. Anticancer Res 2007, 27:2993-2996.

23. Sabel M, Reifenberger J, Weber RG, Reifenberger G, Schmitt HP: Long-term survival of a patient with giant cell glioblastoma. Case report. J Neurosurg 2001, 94:605-611.

24. Sacher A, Wollmann R, Kalokhe U, Munoz D, Guiot MC, Macdonald RL: Long-term survival of a patient with glioblastoma. Can J Neurol Sci 2010, 37:289-292.

25. Sperduto CM, Chakravarti A, Aldape K, Burger P, Papermaster GB, Sperduto $P$ : Twenty-year survival in glioblastoma: a case report and molecular profile. Int J Radiat Oncol Biol Phys 2009, 75:1162-1165.

26. Valery CA, Seilhean D, Boyer O, Marro B, Hauw JJ, Kemeny JL, Marsault C, Philippon J, Klatzmann D: Long-term survival after gene therapy for a recurrent glioblastoma. Neurology 2002, 58:1109-1112.

27. Scoccianti S, Magrini SM, Ricardi U, Detti B, Buglione M, Sotti G, Krengli M, Maluta S, Parisi S, Bertoni F, Mantovani C, Tombolini V, De Renzis C, Lioce M, Fatigante L, Fusco V, Muto P, Berti F, Rubino G, Cipressi S, Fariselli L, Lupattelli M, Santoni R, Pirtoli L, Biti G: Patterns of care and survival in a retrospective analysis of 1059 patients with glioblastoma multiforme treated between 2002 and 2007: a multicenter study by the Central Nervous System Study Group of Airo (italian Association of Radiation Oncology). Neurosurgery 2010, 67:446-458 
28. Sanai N, Polley MY, McDermott MW, Parsa AT, Berger MS: An extent of resection threshold for newly diagnosed glioblastomas. J Neurosurg 2011, 115:3-8.

29. Filippini G, Falcone C, Boiardi A, Broggi G, Bruzzone MG, Caldiroli D, Farina R, Farinotti M, Fariselli L, Finocchiaro G, Giombini S, Pollo B, Savoiardo M, Solero CL, Valsecchi MG, Brain Cancer Register of the Fondazione IRCCS (Istituto Ricovero e Cura a Carattere Scientifico) Istituto Neurologico Carlo Besta: Prognostic factors for survival in 676 consecutive patients with newly diagnosed primary glioblastoma. Neuro Oncol 2008, 10:79-87.

30. Allahdini F, Amirjamshidi A, Reza-Zarei M, Abdollahi M: Evaluating the prognostic factors effective on the outcome of patients with glioblastoma multiformis: does maximal resection of the tumor lengthen the median survival? World Neurosurg 2010, 73:128-134. discussion e116.

31. Oszvald A, Guresir E, Setzer M, Vatter H, Senft C, Seifert V, Franz K: Glioblastoma therapy in the elderly and the importance of the extent of resection regardless of age. J Neurosurg 2012, 116:357-364.

32. Sheehan JP, Shaffrey ME, Gupta B, Larner J, Rich JN, Park DM: Improving the radiosensitivity of radioresistant and hypoxic glioblastoma. Future Oncol 2010, 6:1591-1601.

33. Stupp R, Hegi ME, Mason WP, van den Bent MJ, Taphoorn MJ, Janzer RC, Ludwin SK, Allgeier A, Fisher B, Belanger K, Hau P, Brandes AA, Gijtenbeek J, Marosi C, Vecht CJ, Mokhtari K, Wesseling P, Villa S, Eisenhauer E, Gorlia T, Weller M, Lacombe D, Cairncross JG, Mirimanoff RO, European Organisation for Research and Treatment of Cancer Brain Tumour and Radiation Oncology Groups, National Cancer Institute of Canada Clinical Trials Group: Effects of radiotherapy with concomitant and adjuvant temozolomide versus radiotherapy alone on survival in glioblastoma in a randomised phase III study: 5-year analysis of the EORTC-NCIC trial. Lancet Oncol 2009, 10:459-466.

34. Patel M, Siddiqui F, Jin JY, Mikkelsen T, Rosenblum M, Movsas B, Ryu S: Salvage reirradiation for recurrent glioblastoma with radiosurgery: radiographic response and improved survival. J Neurooncol 2009, 92:185-191.

35. Romanelli P, Conti A, Pontoriero A, Ricciardi GK, Tomasello F, De Renzis C, Innocenzi G, Esposito V, Cantore G: Role of stereotactic radiosurgery and fractionated stereotactic radiotherapy for the treatment of recurrent glioblastoma multiforme. Neurosurg Focus 2009, 27:E8.

36. Lang FF, Miller DC, Koslow M, Newcomb EW: Pathways leading to glioblastoma multiforme: a molecular analysis of genetic alterations in 65 astrocytic tumors. J Neurosurg 1994, 81:427-436.

37. Gil-Benso R, Lopez-Gines C, Benito R, Lopez-Guerrero JA, Callaghan RC, Pellin A, Roldan P, Cerda-Nicolas M: Concurrent EGFR amplification and TP-53 mutation in glioblastomas. Clin Neuropathol 2007, 26:224-231.

38. Sano $T$, Lin $H$, Chen X, Langford LA, Koul D, Bondy ML, Hess KR, Myers JN, Hong YK, Yung WK, Steck PA: Differential expression of MMAC/PTEN in glioblastoma multiforme: relationship to localization and prognosis. Cancer Res 1999, 59:1820-1824

39. Bredel M, Scholtens DM, Yadav AK, Alvarez AA, Renfrow JJ, Chandler JP, Yu IL, Carro MS, Dai F, Tagge MJ, Ferrarese R, Bredel C, Phillips HS, Lukac PJ, Robe PA, Weyerbrock A, Vogel H, Dubner S, Mobley B, He X, Scheck AC, Sikic BI, Aldape KD, Chakravarti A, Harsh GR 4th: NFKBIA deletion in glioblastomas. N Engl J Med 2011, 364:627-637.

40. Wiencke JK, Aldape K, McMillan A, Wiemels J, Moghadassi M, Miike R, Kelsey KT, Patoka J, Long J, Wrensch M: Molecular features of adult glioma associated with patient race/ethnicity, age, and a polymorphism in O6-methylguanine-DNA-methyltransferase. Cancer Epidemiol Biomarkers Prev 2005, 14:1774-1783.

41. Wiemels JL, Wilson D, Patil C, Patoka J, McCoy L, Rice T, Schwartzbaum J, Heimberger A, Sampson JH, Chang S, Prados M, Wiencke JK, Wrensch M: IgE, allergy, and risk of glioma: update from the San Francisco Bay Area Adult Glioma Study in the temozolomide era. Int J Cancer 2009, 125:680-687.

doi:10.1186/1477-7819-10-75

Cite this article as: Thumma et al:: Effect of pretreatment clinical factors on overall survival in glioblastoma multiforme: a Surveillance Epidemiology and End Results (SEER) population analysis. World Journal of Surgical Oncology 2012 10:75.

\section{Submit your next manuscript to BioMed Central and take full advantage of:}

- Convenient online submission

- Thorough peer review

- No space constraints or color figure charges

- Immediate publication on acceptance

- Inclusion in PubMed, CAS, Scopus and Google Scholar

- Research which is freely available for redistribution 